\title{
Motivations and Barriers for the Sustainable Internationalization of the Portuguese Textile Sector
}

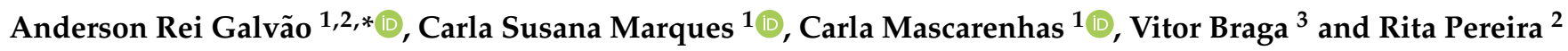 \\ 1 Department of Economics Sociology and Management, University of Trás-os-Montes e Alto Douro \& \\ CETRAD Research Center, 5000 Vila Real, Portugal; smarques@utad.pt (C.S.M.); carlam@utad.pt (C.M.) \\ 2 Escola Superior de Tecnologia e Gestão (ESTG), Polytechnic of Porto, 4610 Felgueiras, Portugal; \\ riti-nha171@hotmail.com \\ 3 Centro de Inovação e Investigação em Ciências Empresariais e Sistemas de Informação (CIICESI), \\ Escola Superior de Tecnologia e Gestão (ESTG), Polytechnic of Porto, 4610 Felgueiras, Portugal; \\ vbraga@estgf.ipp.pt \\ * Correspondence: anderson@utad.pt
}

Citation: Galvão, A.R.; Marques, C.S.; Mascarenhas, C.; Braga, V.;

Pereira, R. Motivations and Barriers for the Sustainable

Internationalization of the Portuguese Textile Sector. Sustainability 2021, 13, 13147. https://doi.org/10.3390/ su132313147

Academic Editor: Bruce Morley

Received: 16 October 2021

Accepted: 22 November 2021

Published: 27 November 2021

Publisher's Note: MDPI stays neutral with regard to jurisdictional claims in published maps and institutional affiliations.

Copyright: (c) 2021 by the authors. Licensee MDPI, Basel, Switzerland. This article is an open access article distributed under the terms and conditions of the Creative Commons Attribution (CC BY) license (https:// creativecommons.org/licenses/by/ $4.0 /)$.

\begin{abstract}
This study aims to analyse the importance of internationalization for the sustainability of companies in the textile sector, as well as to identify the main motivations and barriers to internationalization. For the development of the study, a qualitative methodology was used through interviews with six Portuguese companies in the textile sector. The collected information was submitted to a content analysis, through data coding with NVIVO 11.0 software. The results obtained show the main motivations for internationalization, the criteria used for choosing the countries to internationalize, the advantages of internationalization and the external and internal barriers. This study contributes to a deeper understanding of internationalization, the barriers that companies in the textile sector face and what solutions they find to overcome some of these same barriers. In addition, the results will help policy makers define policies to support internationalization.
\end{abstract}

Keywords: internationalization; barriers; SMEs; textile sector; sustainability; Portugal

\section{Introduction}

The world economy has been determined by an increase in the number of international transactions. Each national market has given way to a global market, creating new spaces for formal integration that act as facilitators of commercial exchanges, thus allowing new players and business models to emerge $[1,2]$. With globalization, and the accompanying increase in international competition and the demand of markets, companies are forced to look for new ways to stay in the market [3]. Thus, the search for new markets, new realities and new partners is imperative for current business strategies [4]. According to Simões [5], internationalization is a gradual process of the evolution of companies' involvement in international business operations. As a rule, companies strengthen their positions abroad as they accumulate international experience and improve their knowledge of operating conditions abroad [6]. Internationalization is the process by which a company increases the level of its value-added activities outside its country of origin [7].

In this sense, more and more companies are opting for internationalization, because they believe it helps to (i) improve their production efficiency, (ii) improve the profit base to reward shareholders and employees, (iii) generate more resources for reinvestment and growth and (iv) diversify the business risks of operating in various markets [8].

Although there are several benefits arising from internationalization, a company's entry into foreign markets is not always easily achieved [9]. Instead, the company may face quite serious barriers/obstacles, the most common being: limited organizational resources; inadequate marketing strategy; restrictive international trade rules and regulations; the business practices and habits of unfamiliar and/or different customers abroad; excessive 
costs due to the great geographical and psychological distances that separate nations; concerns about social and environmental sustainability [10]. According to Erraach et al. [11], in recent years, there has been high concern with environmental and social sustainability on the part of consumers, which has led to some limitations on the part of companies that intend to internationalize. These obstacles can limit a company's potential to explore opportunities in the foreign market, weaken its financial performance, delay its progress on the path to internationalization or even cause it to abandon operations abroad altogether [12].

Although there are a substantial number of studies that investigate the role of motivations and barriers in the internationalization behavior of companies, a recent review found most of these studies are marked by serious conceptual, methodological and empirical limitations $[9,13]$. According to some authors [14,15], the motivations and barriers to internationalization can vary depending on a company's sector of activity, the stage of internationalization in which the company is located, or the country where the company is located or intends to operate. In this sense, it is extremely important that there are more empirical studies that address the motivations and barriers to internationalization from different perspectives, countries and sectors of activity $[12,15,16]$. Although some studies [17-19] have explored the motivations and various barriers to internationalization, this research still lacks an empirically tested theoretical basis [16]. In this case, in the Portuguese textile sector there are some studies on internationalization, but they only focus on cooperation alliances [20,21] or the export performance of companies [22].

In order to fill the identified gaps, this study aims to understand the importance of internationalization for the sustainability of companies in the Portuguese textile sector, as well as to identify the main motivations and barriers to internationalization.

The Portuguese textile sector is a traditional sector and one of the oldest in Portugal. In addition, it is one of the most important sectors in terms of foreign trade, with $80 \%$ (2016) of its production (textiles and clothing) being exported to 189 countries on five continents [23].

According to data from INE, in 2016, the textile and clothing sector encompassed 12,227 companies, which represents $18.3 \%$ of the total national manufacturing industry. In terms of size, SMEs are most relevant in this sector, representing 40 percent of textile and clothing companies, 75 percent of turnover and 77 percent of workers [23]. Thus, the situation and evolution of the textile and clothing sector have largely been influenced by the behavior of SMEs [23]. About 61 percent of turnover in the textile and clothing industry has been reported to come from exports [23].

To carry out this study, a qualitative analysis was used, and through the case study, interviews were held with those responsible for the internationalization of companies in the textile sector (SME). The interviews were subjected to content analysis and data coding using NVIVO software.

After this introductory point, a brief theoretical discussion will be made about the importance of internationalization for companies, and the main barriers to internationalization. In point three, the methodology used in the study will be addressed. In the next section, the results obtained will be presented, as well as their discussion. Finally, in the last point, the main conclusions, implications, limitations and future investigations will be presented.

\section{Literature Review}

\subsection{Motivations for Internationalization}

With the phenomenon of globalization, markets have become increasingly open and competitive, thus contributing to companies changing their way of operating [24]. More and more companies are oriented towards internationalization in order to be less dependent on the domestic market and obtain a greater maximization of their profits [8].

Internationalization provides for the exploration of the core competencies of companies in new markets and the increase in economies of scale and experience [25]. Although it is not the only solution to the challenges that companies face, internationalization has 
come to be seen not only as a competitive advantage, but also as a way of surviving the crisis that is currently prevalent [26]. In order to ensure long-term competitive success, it is important to adjust the degree of internationalization of a company to market trends and competition [25].

According to Hollensen [27], the main reason for internationalization, in a very reducible and pragmatic way, is to make money. However, the same author [27] assumes that, as would be expected, an exceptionally single factor is sufficient reason to develop some type of action. Therefore, they point out other motivations for internationalization, dividing them between proactive and reactive motivations, a distinction that had already been made by other authors [28,29]. Proactive motivations refer to stimuli that aim to change an organization's strategy, based on the exploitation of unique resources or skills, while reactive motivations seek to explain a company's reactions, pressures or threats from domestic or international markets, with companies portrayed as adjusting through changes in their routines and activities developed $[27,28]$.

On the other hand, there are authors who distinguish between internal motivations for internationalization (i.e., company growth, higher profits, prestige) and external motivations (i.e., saturated domestic market/high competition, social ties, economies of scale, networks) for a company [30,31]. According to Williams [32], the decision to start internationalization seems to be influenced by multiple stimuli rather than a single stimulus, although some stimuli may have a relatively greater impact on the decision-making process. Prestige, growth in foreign markets and higher profits are often reported as important internal drivers for companies with international activities [33-35]. Among the external motivations, the saturation/stagnation of domestic markets and competitive pressure on domestic markets are reported as stimuli that lead companies to seek opportunities abroad [36-39]. In addition, companies appear to be motivated to internationalize by external environmental factors, including assistance/incentives from government or external organizations, contacts after participation in trade fairs, unsolicited requests from social groups abroad and social ties [34,37,38,40].

According to Child and Rodrigues [41], the fear of remaining in an overly competitive domestic market, with low profit margins, motivates companies to seek new markets. Singh, Gaur and Schmid [42] also present the same line of thought, arguing that companies internationalize in an attempt to overcome the disadvantages of operating only in the domestic market, primarily the satiety of the market, which can be characterized by high internal competition. As for Johanson and Vahlne [43], the question of opportunities turns out to be the most important and decisive. Additionally, according to the authors [43], companies must focus on the opportunities that appear. Nevertheless, competitive advantages held by SMEs, such as technological know-how, organisational flexibility and close client relationships, are key factors acting as main drivers to internationalization [44].

In this sense, internationalization, in addition to improving the performance of a company, can contribute to the economic development of nations through the development of national industries, improving productivity and creating jobs [45]. The internationalization of these companies can help improve employees' working conditions, environmental outcomes and the sustainability of the textile industry [46]. Furthermore, operating in foreign markets can allow a company to benefit from competition and increase its involvement in the foreign market, thus becoming a stronger player in its domestic market. Indeed, the importance of the textile industry to emerging economies is difficult to overstate, and thus research is required into the industry's internationalization strategies and motivations, as well as its sustainability in production, processes and industry structure [47].

\subsection{The Barriers to Internationalization}

Despite the numerous benefits expected from the internationalization process, starting a company's operations in foreign markets is not always easy, since organizations are faced with several barriers [48]. Barriers represent the constraints that impede a company's ability to initiate, develop or sustain business operations in foreign markets [17]. The perception 
of internationalization barriers by decision makers in organizations is one of the key factors that shapes the internationalization behavior of companies [49].

According to some authors [9,17,50-52], barriers can be internal to the company (e.g., a lack of financial, strategic, or managerial resources and capabilities, operational difficulty in selecting reliable distributors, a lack of negotiation power, little understanding of target markets and their challenges, an inability to achieve competitive advantage in foreign markets, etc.) or external (e.g., the home country's institutional environment and various factors in foreign locations, such as unfamiliar business protocols, high tariffs and tax structures, cultural differences, a lack of proper trade institutions, a lack of incentives and protection from the government, political instability, legal and political problems, political instability, demand insufficiency, etc.). In fact, currency exchange, market entry barriers and trust are the most important challenges faced by small exporters [52]. Likewise, Leonidou [9] argues that the lack of management, human and financial resources is the main barrier that prevents companies from starting or increasing their export activities. Furthermore, Rutashobya and Jaensson [53] report on a number of barriers to internationalization, including financial resources, management and marketing skills, foreign exchange risk management for exports, knowledge, a lack of foreign language knowledge, cultural experience, insufficient knowledge of foreign market information, fear of foreign market risks, and previous export experience.

The European Commission [54] identified the barrier most cited by companies as the high cost of the internationalization process, that is, costs associated with market analysis, purchases, legal advice, the translation of documents, the adaptation of products to the foreign market, commercial risk and other financial costs incurred. The OECD [55], on the other hand, identified as the main barriers faced by companies political risk, the problem of international compatibility, corruption, the issue of rules of law, and issues related to the protection of intellectual property.

As a rule, the resources and capabilities of companies are limited, which creates several problems for internationalization [56,57]. According to Suarez-Ortega [58], resource dependence can be seen as one of the main reasons why many companies, especially small and medium-sized ones, prefer to maintain a strategy oriented towards the domestic market $[14,58]$.

In this sense, the theory of resource dependence has focused on the acquisition of resources in organizations and on how organizations deal with these limitations [59]. A key assumption in this theory is that actors do not control all the relevant resources they need (resources are scarce), but depend on other actors to gain access to the critical resources they need [59,60]. According to Pfeffer [61], organizations are usually connected by a network of interdependencies with other organizations, and they often take actions to manage external interdependencies [62]. In the case of internationalization, the greater a company depends on the resources of another company, the greater its barriers to internationalization may be $[63,64]$.

\section{Methodology}

\subsection{Characterization of the Textile Sector in Portugal}

According to data from the Bank of Portugal [23], in 2018, the Portuguese Textile and Clothing industry consisted of around 6700 companies, which employ around 130 thousand direct workers and generate around 7610 million euros in volume of business (Table 1). 
Table 1. Characterization of the textile sector in Portugal.

\begin{tabular}{cccccc}
\hline Textile Sector in Portugal & $\mathbf{2 0 1 4}$ & $\mathbf{2 0 1 5}$ & $\mathbf{2 0 1 6}$ & $\mathbf{2 0 1 7}$ & $\mathbf{2 0 1 8}$ \\
\hline Production (million $€$ ) & 6485 & 6767 & 7147 & 7439 & 7500 \\
Turnover (million $€$ ) & 6712 & 6942 & 7362 & 7607 & 7610 \\
Exports (million $€$ ) & 4620 & 4811 & 5036 & 5215 & 5314 \\
Imports (million $€$ ) & 3608 & 3835 & 3940 & 4139 & 4307 \\
Job & 128,414 & 131,513 & 135,521 & 136,928 & 138,000 \\
\hline
\end{tabular}

Source: Pordata.

In 2018, it was one of the most important sectors of the national economy, boasting around $10 \%$ of national exports, $19 \%$ of manufacturing industry employment and $8 \%$ of manufacturing industry turnover [65]. It is one of the few sectors of activity with a positive balance in the trade balance of goods, often recording a balance of more than one billion euros [65]. According to the Portuguese General Directorate of Economic Activities [66], in 2016, the Portuguese Textile and Clothing Industry (ITV) was mostly located in the north of Portugal (76.1\%), followed by the Center Region and the Lisbon metropolitan area (10.6\% and $9.2 \%$, respectively). In the North Region, the following sub-regions predominate: Ave (39\% of the ITV's total business), Porto metropolitan area ( $20 \%$ of the ITV's turnover), Cávado (19\% of the ITV's turnover) and Tâmega and Sousa ( $8 \%$ of total turnover). In the Center Region, the predominant regions are Aveiro (3\% of total turnover) and Beiras and Serra da Estrela (about 3\% of the ITV's business) [65].

The activity of making outer clothing, except leather clothing and work clothing, is the one that generates the highest turnover ( $38 \%)$, followed by textile weaving $(9 \%)$ and the manufacturing of manufactured textile articles, except clothing, among which include home textiles (7\%) and textile finishing (7\%) [65]. Portugal is one of the main European players in terms of the textile and clothing industry, ranking sixth in terms of turnover and fourth in terms of employment [66].

Strongly geared towards exports, this industry's main destinations of choice are in European Union markets (Figure 1), with Spain representing 32\% of the industry's total exports in 2018. The US is the main non-EU destination, representing around $6 \%$ of the total national exports of textiles and clothing in 2018.

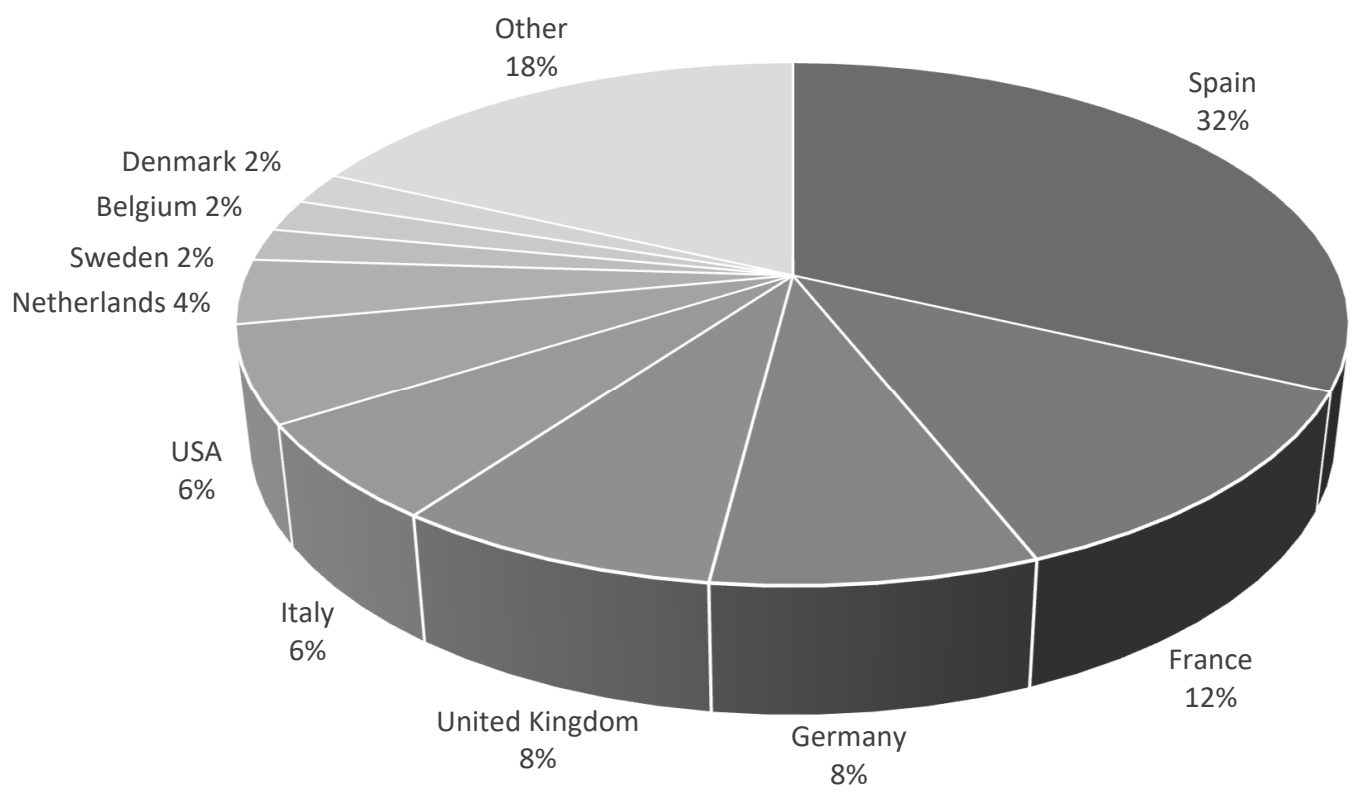

Figure 1. Main customers of the textile sector (Source: Eurostat: year 2018). 
In terms of supply (Figure 2), Spain continues to lead the table of main suppliers (39\% of total imports). China is the most important non-EU market, accounting for around $6 \%$ of total imports in 2018.

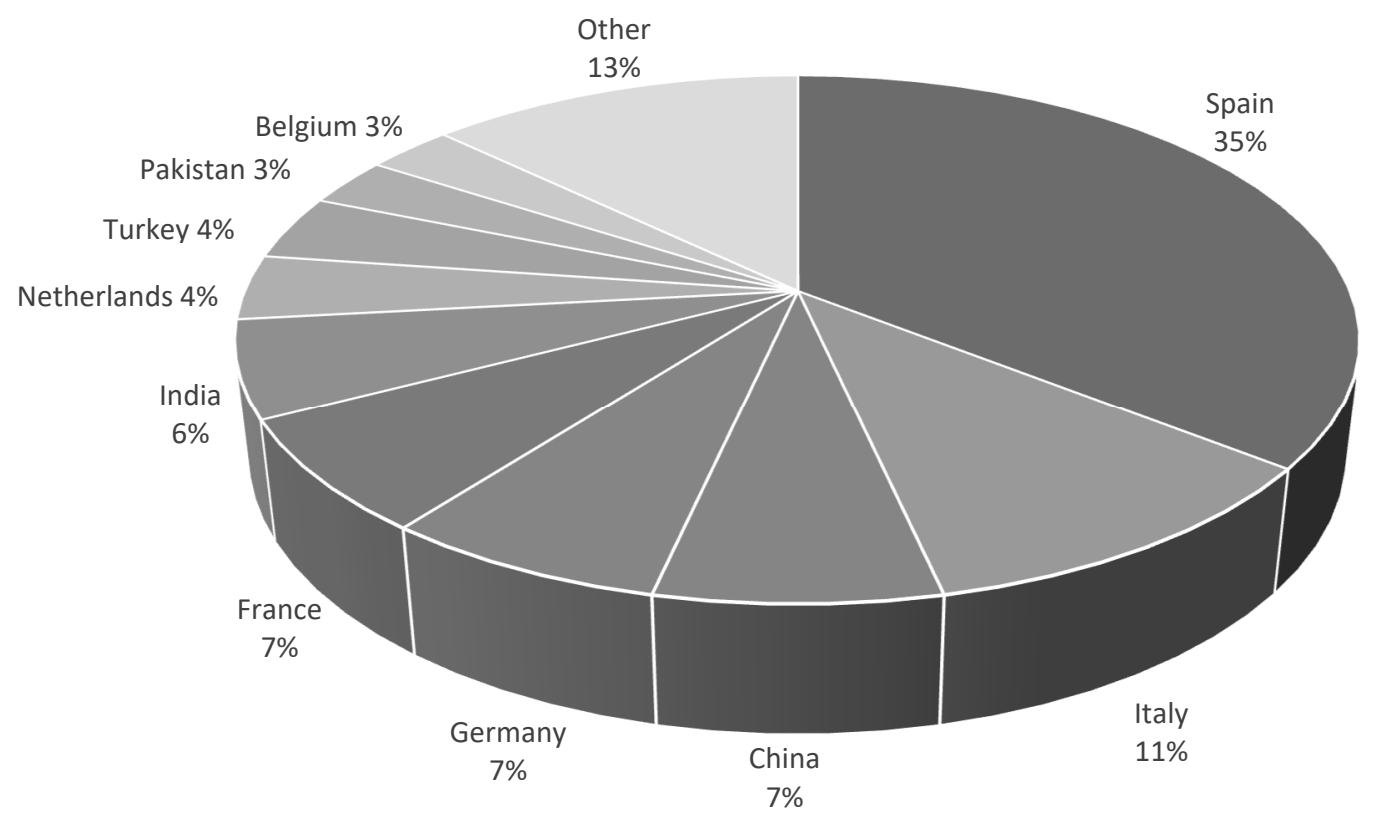

Figure 2. Main suppliers in the textile sector (Source: Eurostat: year 2018).

Textiles and clothing "made in Portugal" have achieved a strong international reputation, which places the industry today among the most advanced and best performing manufacturing industries in the world, and, being a truly successful case study, it is studied in schools, businesses and universities on all continents [66]. If today the "made in Portugal" label adds value to textile materials that come from national companies, which is why international customers demand its placement, in the past, not yet very remote, it was precisely the opposite. This reality is the result of a long and arduous achievement, carried out by companies in the sector and by entities such as the Portuguese Textile and Clothing Association, which represents it and knew how to give it a strategic direction, in addition to putting a set of instruments at its service, without which the change of orientation would not have been possible to achieve [65].

\subsection{Type of Study and Case Selection}

This study aims to investigate the motivations and barriers to the internationalization of Portuguese companies in the textile sector. Thus, we opted for a qualitative analysis, through six case studies. Each case study corresponds to a small and medium-sized enterprise in the Portuguese textile sector that is heavily dependent on exports (exports represent $90 \%$ or more of turnover). For Yin [67], a case study is a form of qualitative approach that examines a current phenomenon in its context, especially when the boundaries between the phenomenon and the context are not clearly defined. For research with a qualitative approach, the sample size can be small, since depth and richness are the key elements, with there being no need to generalize or replicate the findings [68]. According to Perren and Ram [69], qualitative methods have been gaining interest from management and small business researchers, as the qualitative technique allows for the gathering of information that leads to results that certainly could not be measured or translated into numbers [70].

The case study method uses a variety of evidence from different sources, such as documents, observation and interviews. One of the most important features of the case study is its ability to carry out the investigation of a phenomenon in its real environment [71].

To carry out this study and to select the cases, the following criteria were used:

1. Identification of companies in the textile sector that are heavily dependent on exports; 
2. Selection of companies for convenience: ease of access to information;

3. Companies with different characteristics: despite these companies being in the same sector of activity, it was decided to select companies with different characteristics, such as size, countries they had expanded into, market segments, etc.

In this sense, Table 2 presents the six companies that participated in this study.

Table 2. Characterization of interviewed companies.

\begin{tabular}{|c|c|c|c|c|c|c|}
\hline Company & Location & $\begin{array}{l}\text { Year of } \\
\text { Start of } \\
\text { Activity }\end{array}$ & $\begin{array}{c}\text { No. of } \\
\text { Collaborators }\end{array}$ & Sector & $\begin{array}{c}\% \\
\text { Export }\end{array}$ & $\begin{array}{l}\text { Main Export } \\
\text { Markets }\end{array}$ \\
\hline 1 & Quinchães & 1996 & 90 & $\begin{array}{l}\text { Serial outerwear } \\
\text { manufacturing }\end{array}$ & $100 \%$ & $\begin{array}{c}\text { Spain } \\
\text { Italy } \\
\text { United Kingdom }\end{array}$ \\
\hline 2 & Quinchães & 2016 & 17 & $\begin{array}{l}\text { Serial outerwear } \\
\text { manufacturing }\end{array}$ & $100 \%$ & $\begin{array}{l}\text { Spain } \\
\text { Turkey } \\
\text { Morocco }\end{array}$ \\
\hline 3 & Medelo & 1993 & 34 & $\begin{array}{l}\text { Manufacture of } \\
\text { underwear, other } \\
\text { articles and } \\
\text { clothing } \\
\text { accessories }\end{array}$ & $90 \%$ & Spain \\
\hline 4 & $\begin{array}{l}\text { Vila Nova } \\
\text { de } \\
\text { Famalicão }\end{array}$ & 1937 & 190 & $\begin{array}{l}\text { Finishing fabrics } \\
\text { and knits }\end{array}$ & $100 \%$ & $\begin{array}{c}\text { Spain } \\
\text { United Kingdom } \\
\text { France } \\
\text { Finland } \\
\text { Germany }\end{array}$ \\
\hline 5 & Paços & 2013 & 3 & $\begin{array}{l}\text { Clothing, footwear } \\
\text { and leather } \\
\text { industry }\end{array}$ & $90 \%$ & Germany \\
\hline 6 & Quinchães & 2000 & 79 & $\begin{array}{l}\text { Serial outerwear } \\
\text { manufacturing }\end{array}$ & $100 \%$ & $\begin{array}{c}\text { Spain } \\
\text { England }\end{array}$ \\
\hline
\end{tabular}

Based on the data presented in the table above, we will make a brief presentation of the companies that participated in this study, referring to the region, type of company, and what they produce, among other characteristics.

\subsection{Data Collection and Processing}

The purpose of data collection is to obtain a set of information that addresses the topic under study and captures its contextual complexity $[72,73]$. To this end, we resorted to obtaining primary data through interviews, individual and semi-structured, conducted by a script with the core questions of the study. The interviews allowed for the collection of more complete and spontaneous answers through the interaction between the interviewer and the interviewee, thus avoiding problems related to the interpretation of the questions [74].

The interview guide used in this study was divided into three parts. The first part is related to the identification of the interviewees and the company under study. The second part contains open questions about the internationalization process in order to understand the company's main motivations, the criteria for choosing the country and the advantages of internationalizing. The third and last part contains open questions about the main internal and external barriers encountered at the time of internationalization, and how these barriers were overcome. In Table 3, it is possible to observe in more detail the questions asked in the interviews. 
Table 3. Interview script.

\begin{tabular}{|c|c|}
\hline 1st part & $\begin{array}{l}\text { - Identification of the respondent: name, gender, age, educational qualifications, } \\
\text { position in the company and years of service. } \\
\text { - Company identification: Name, location, year of beginning of activity, number } \\
\text { of employees, main export markets, percentage of exports. }\end{array}$ \\
\hline 2nd part & $\begin{array}{l}\text { What were the reasons / motivations that led to your company's } \\
\text { internationalization? } \\
\text { When the company chooses a country to internationalize, what criteria does it } \\
\text { take into account? } \\
\text { Is the entry strategy the same for all markets? If not, what are the main } \\
\text { differences? } \\
\text { What were the benefits of internationalization for your company? Why? }\end{array}$ \\
\hline 3rd part & $\begin{array}{l}\text { - What were the main internal barriers found that the company had to overcome } \\
\text { during the internationalization process? } \\
\text { - What were the main external barriers found that the company had to overcome } \\
\text { during the internationalization process? } \\
\text { - What did the company do to overcome internal barriers? }\end{array}$ \\
\hline
\end{tabular}

The interviews were conducted in person or by videoconference from June to August 2020, with their average duration being $30 \mathrm{~min}$, and were held with those responsible for the internationalization of the companies under study (Table 4).

Table 4. Characterization of respondents.

\begin{tabular}{lclcccc}
\hline Company & Interviewee & Gender & Age & $\begin{array}{c}\text { Academic } \\
\text { Education }\end{array}$ & Office & $\begin{array}{c}\text { Years in the } \\
\text { Company }\end{array}$ \\
\hline Company 1 & Interviewee 1 & Male & 33 & $\begin{array}{c}\text { High } \\
\text { school }\end{array}$ & Logistics & 7 years \\
\hline Company 2 & Interviewee 2 & Female & 44 & Graduation & $\begin{array}{c}\text { General } \\
\text { Director }\end{array}$ & 4 years \\
\hline Company 3 & Interviewee 3 & Female & 26 & Graduation & Commercial & 3 years \\
\hline Company 4 & Interviewee 4 & Male & 50 & Graduation & $\begin{array}{c}\text { Responsible } \\
\text { for R\&D }\end{array}$ & 20 years \\
\hline Company 5 & Interviewee 5 & Female & 44 & Graduation & $\begin{array}{c}\text { Customer } \\
\text { Manager }\end{array}$ & 7 years \\
\hline Company 6 & Interviewee 6 & Male & 43 & $\begin{array}{c}\text { High } \\
\text { school }\end{array}$ & Manager & 20 years \\
\hline
\end{tabular}

Finally, all the information collected (interviews) was submitted to a content analysis. By organizing sources and coding data with NVIVO 11.0 software, it was possible to extract useful and segmented information, which resulted in the creation of tree nodes (trees of nodes), which labeled and branched the collected information. In cases where the information was very dispersed in its content or lacking sufficient elements to capture patterns, and due to coding difficulties, word cloud analysis was used.

\section{Results and Discussion}

\subsection{Internationalization Process}

Today, internationalization is a persistent concern of the management teams of companies all over the world. The internationalization process can be defined as a process by which a company develops its operations beyond its national territory, either through its commercial operations (import and export) or through investment. According to Sousa [75], in the current Portuguese economic situation, companies are forced to reinvent themselves and expand in order to survive in highly competitive markets. 
Internationalization appears as an option for overloaded domestic markets. In the internationalization process, companies must first identify the periods of their international activity, while also clarifying their objectives and motives. Then, they must select the business to internationalize, the mode of entry and the country of destination. They should also keep in mind that it is not an easy process, but with the proper management, they will achieve greater returns in the future [39]. Given the competitiveness and sustainability imperatives of different types of firms, which are often linked to their international enlargement, including entering new markets, exploring new strategies and new resources, mapping business prospects, and seeking sustainable competitive advantages, internationalization has become crucial to a great majority of firms [76]. Internationalization is the direction for firms to achieve organizational competitiveness and sustainability, especially in an era where survival is dependent on environmental and economic issues [76].

Figure 3 shows that the internationalization process is associated with a company's motivations, which in turn are related to the criteria used to choose the country that will bring more advantages. The respondents recognized that the choice of the market and how they enter the market are very important factors in the internationalization process.

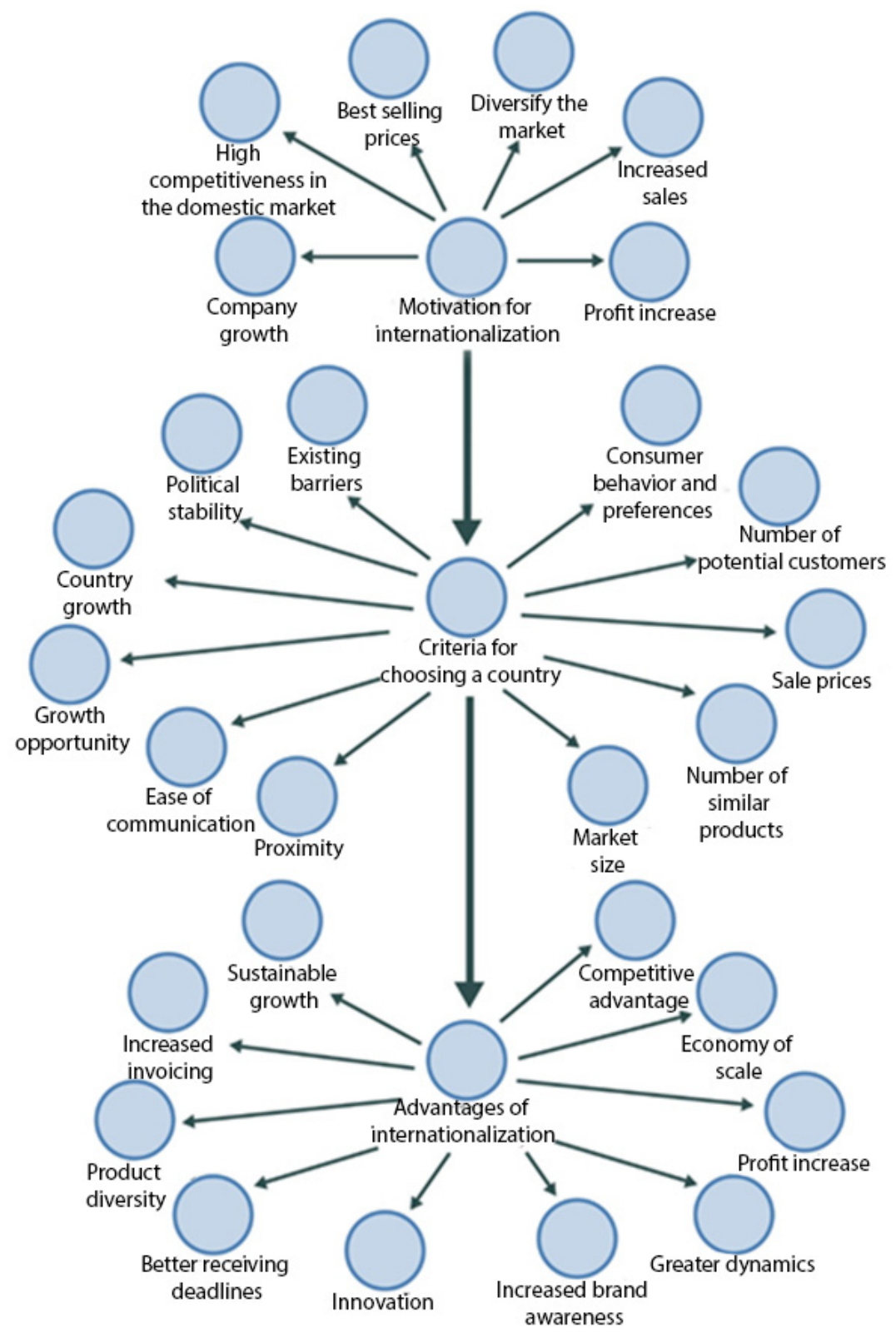

Figure 3. Map of nodes (NVivo) for the results of the interviews. 


\subsubsection{Motivations for Internationalization}

There are several motivations that lead companies to expand abroad. According to Czinkota et al. [77], if, on the one hand, there are proactive motivations, which involve advantages in terms of profits, technology, exclusive information, management commitment, tax benefits and economies of scale, on the other hand there are reactive motivations that relate to pressures from the competition, excess production capacity, excess capacity, declining domestic sales, saturation of the domestic market and proximity to customers. In addition, Teixeira and Diz [24] mention six motivations: access to cheaper and "better" resources, greater returns on investment, increases in market share, avoidance of imports or import quotas, the responses of customers and competitors and access to skills.

For Buckley et al. [78], market research is one of the motivations that can lead to the internationalization process. Thus, according to the interviewees, the main motivations for advancing in the internationalization process are related to the small size of the Portuguese market, the need to increase sales volume and profits, the expansion of business, and increased competitiveness and economies of scale:

Interviewee 1: "As the Portuguese market is a very small market, the company internationalized itself to achieve a greater volume of sales and, consequently, an increase in profits. [... ]".

Interviewee 5: "[ ... ] On the financial side, foreign customers are more assertive and compliant with regard to payment, which allows for greater security and stability".

Interviewee 4: "The expansion of the business, making the business known on a large scale, the increase in turnover, the increase in competitiveness, the more inserted in other markets, the greater the existing competitiveness".

\subsubsection{Criteria for Choosing a Country}

In the internationalization process, the considered selection of destination countries can define whether the entire process is successful or not. It is therefore necessary for companies to carry out a careful analysis of their target markets [79]. As a rule, companies in the initial phase of internationalization approach markets that seem simpler, more familiar and less costly to enter, coinciding with markets that are close in physical and cultural terms, and over time the process includes markets that are increasingly distant in political, cultural, economic and physical terms [80].

According to the interviewees, the main criteria that were taken into account when choosing the countries to enter were related to market size, cultural and linguistic aspects, low costs and geographic proximity.

Interviewee 2: "The country's politics, language barriers, taxes charged by the country, higher prices, culture that can be quite distant and influence [ ... ]".

Interviewee 3: "[ ... ] Prices used by the country, ease of communication, creating a good relationship with customers, captivating them to prolong this connection and eventually expanding knowledge through these same companies/customers".

Interviewee 4: "It depends on the strategy, positioning of the company and the business itself; however, the main criteria are: the proximity (control of logistical costs); markets with constant GDP growth; target market size; understanding the culture of the target audience, that is, perfect understanding of consumer behavior; opportunity for rapid growth due to a lack of competition from similar products $[\ldots]^{\prime \prime}$.

\subsubsection{Advantages of Internationalization}

According to Lorga [26] and Freire [25], internationalization provides companies with more advantageous production conditions, the acquisition of existing know-how in other countries, exploration of their core competencies in new markets and increased economies of scale and experience. In addition, internationalization can be an opportunity for companies to become more efficient and sustainable in order to obtain a competitive advantage, as they can overcome a lack of resources, gain a wider range of customers, increase productivity and reduce costs [81]. With regards to the companies under study, respondents reported 
that the main advantages they obtained with internationalization were their companies' growth, increased turnover, increased reputation, increased dynamics, and making their companies more competitive and innovative.

Interviewee 3: "[ ... ] General growth of the company, whether in terms of facilities, machines and employees. Also a greater amount of orders and profit".

Interviewee 2: "International markets are the best tool for the continuity of a company in the textile sector. [ ... ]".

Interviewee 6: "The advantages of internationalization for the company were the economic support that the different countries we work with allow us to have and the recognition of our product in other countries. [ ... ]".

\subsection{Barriers to Internationalization}

Barriers to internationalization have a particular impact on small- and medium-sized companies [46], as it is assumed that they have fewer resources and less competitive advantages, and are therefore less capable of successfully internationalizing [82]. Some authors [46,82-84] mention some obstacles to internationalization, namely, the low selffinancing of companies, weak productive capacity, a lack of qualified human resources, reduced knowledge of foreign languages and markets and the fact that there are no joint ventures in foreign markets, as factors that complicate the entry of companies into international markets.

Internationalization exposes companies to risks and insecurities that must be considered before deciding to proceed with the internationalization process [85]. However, if a company manages to recognize what distinguishes it from its competitors, and gathers other favorable conditions for internationalization, the company will have sufficient motivation to start this process [86].

Figure 4 illustrates some of the barriers identified by respondents, as well as the strategies they implemented to overcome these barriers.

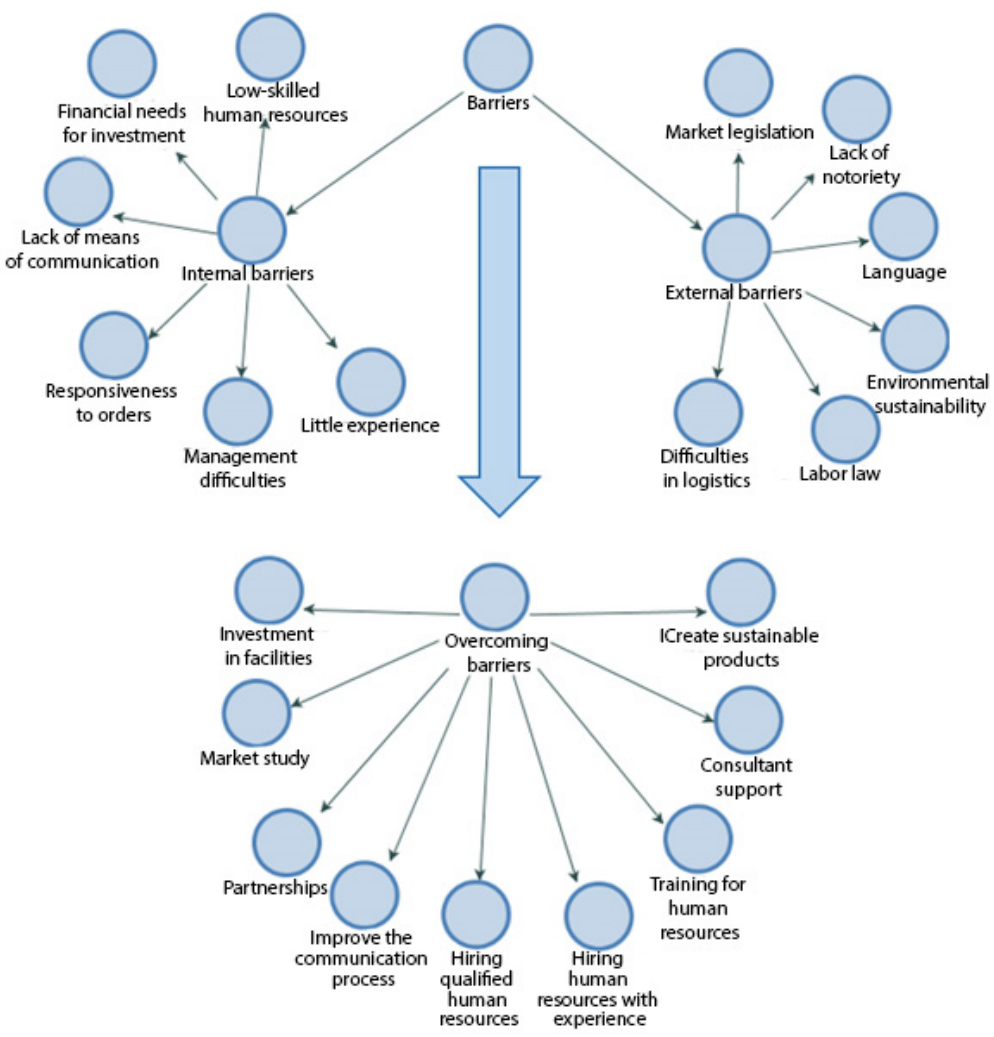

Figure 4. Main barriers faced by Portuguese companies in the textile sector in the internationalization process. 


\subsubsection{Internal and External Barriers}

Barriers to internationalization can be divided between internal and external barriers, with internal barriers being related to a company's capabilities and competences, and external barriers being related to factors beyond the company's control [87].

In the case of the companies interviewed, it was possible to verify that the internal barriers were related to a lack of financial resources, which makes investment difficult, a lack of experience and the organization of the companies (response capacity, management difficulties, lack of means of communication).

Interviewee 3: "The lack of good means of communication at the beginning, being often necessary to go to the headquarters of the client's company to resolve any issue (e.g., Madrid, Santa Pola, Pamplona, Bilbao, ... ). Lack of monetary means to invest in machinery and raw materials. [ ... ]".

Interviewee 1: "Poorly qualified human resources and little experience were the main internal barriers to the company's internationalization. [ ... ]".

Interviewee 5: "Respond quickly and efficiently to orders [ ... ]".

On the other hand, external barriers are related to logistical difficulties, labor legislation, taxes, language and the lack of reputation of the companies in the destination country. In addition, some respondents recognized that consumer concerns for more sustainable products have been a barrier in an industry as vibrant as textiles.

Interviewee 4: "[ ... ] The language, lack of qualified personnel, the slow logistical process and the absence of an attractive fiscal policy that encourages companies to make the decision".

Interviewee 2: "[ . . ] Scarce government aid and banking entities to be able to make more investments, there are no more favorable policies for those who want to invest in another country and internationalize the company, the lack of qualified personnel in foreign trade to be able to carry out a market study that allows the company to have the awareness of the decision to be made".

\subsubsection{Overcoming Barriers}

The ability to support international activities depends on the interaction that exists between a company's internal repressions and the conditions of the external environment, as well as the company's ability to strengthen strategies that allow it to minimize or overcome the identified obstacles [88]. Some of these challenges, particularly at the macro level, such as currency devaluation and bureaucratic and regulatory issues, are common to multiple companies and independent of the sectors they compete in, while others are specific to each company or even the market where it will operate and the type of industry it represents. According to the interviewees in this study, to overcome the identified barriers, there must be a set of measures, both from companies and from destination countries, that allow for greater ease in the internationalization process. In this sense, the interviewees stated that the main ways they found to overcome the barriers were through training human resources, specialized support from consultancy companies, hiring qualified human resources, creating partnerships, investing in facilities or in the production process and the creation of more sustainable and environmentally friendly products.

Interviewee 1: "[ ... ] Regular training and hiring of more qualified employees".

Interviewee 2: "Accompaniment by experts who help us to improve the situation and guide us in the best way to achieve our goal. [ ... ]".

Interviewee 4: "Assertive partnerships with companies that added value to the business $[\ldots]^{\prime \prime}$.

Interviewee 5: “[ ... ] Improve the production process [ ... ]. Investing in the innovation of more environmentally friendly products $[\ldots]$ ".

\section{Conclusions}

This study aimed to identify the barriers faced by Portuguese companies in the textile sector in the internationalization process. The results allow us to conclude that the 
motivations that lead companies to internationalize are, essentially, incentives for their growth and survival, such as: the saturation of the internal market and greater financial stability. Internationalization offers small businesses opportunities for market growth, sustainability, less reliance on local markets, and economies of scale. However, this process also includes barriers, which can lead to discouragement, so it is essential that companies are prepared to overcome them. Considering the case studies carried out in this paper on several companies, the main barriers mentioned were cultural, political, economic, human resources and logistical differences.

Regarding the countries to which companies have expanded, it can be concluded that companies, in general, are betting on countries that are geographically and culturally closer, due to greater ease of entry into the market. Thus, it is concluded that due to the small Portuguese domestic market and the high competition in the textile sector, companies in this sector have had to focus on internationalization in order to achieve economies of scale to, in turn, become more competitive and sustainable.

It is expected that this work will contribute to discussions on the internationalization of SMEs by providing new knowledge on the subject and taking into account the opportunities and threats to which these types of companies are subject. The aim of this study is to provide theoretical and empirical evidence that provides a more integrative view of the internationalization of SMEs.

In terms of theoretical implications, our results reveal that there are several internal and external barriers to the internationalization of SMEs. Therefore, SME managers must undergo rigorous internal management processes in order to overcome the barriers that make their internationalization difficult or impossible. It will also be necessary to form partnerships between SMEs and international collaborators in order to overcome the barriers they face, especially the external ones. This will strengthen their capacity to generate resources to deal with the identified barriers.

In terms of practical implications, our results can help other SMEs, as well as policy makers, to be able to identify the barriers to behavior that must be overcome in order to sustain the success of SME internationalization. The study thus expands our knowledge of the previously limited set of barriers that SMEs and international entrepreneurs face. In fact, this research identified the barriers and challenges of the international interactions of SMEs, which are not limited to language, currency or economic barriers. The conclusions drawn from the results of this investigation present some practical implications, which are expected to contribute to the literature. The various barriers, both internal and external, to the internationalization of SMEs trigger the necessary internationalization mechanisms in different ways. With the current crisis triggered by the COVID-19 pandemic, many firms are struggling to survive, acquire financial sustainability, and develop effective strategies without compromising their values. This study can highlight the processes to support internationalization in a period such as the one firms are currently operating in. The method of this study can also be applied in other fields.

With regards to the development of this study, some limitations were found, namely, the subjectivity in the analysis of the results and in the coding and categorization system of the interviews. Despite having taken all the recommended precautions, qualitative methodology studies always present some subjectivity. Another limitation is related to the period in which the interviews were conducted. The interviews were conducted during a period of confinement due to COVID-19, which made it difficult to gather information and impacted the availability of other companies to participate in the study. The last limitation identified is that the study was carried out for only one sector of activity. However, some of the limitations may serve as a starting point for future investigations, such as extending this study to other sectors of activity or countries in order to understand which limitations are common. Another research proposal involves studying the effectiveness of export incentive policies and how these policies help to reduce the main barriers. Finally, it would be interesting to study companies that have failed in the internationalization process. 
Author Contributions: Conceptualization, R.P. and A.R.G.; methodology, R.P.; software, A.R.G.; validation, A.R.G., C.S.M.; funding acquisition, A.R.G., C.S.M.; Writing-original draft, R.P., C.S.M.; writing-review and editing, A.R.G., C.M., V.B. All authors have read and agreed to the published version of the manuscript.

Funding: This work is supported by national funds, through the FCT-Portuguese Foundation for Science and Technology under the project UIDB/04011/2020.

Institutional Review Board Statement: Not applicable.

Informed Consent Statement: Informed consent was obtained from all subjects involved in the study.

Acknowledgments: FCT—Fundação para a Ciência e Tecnologia through project UIDB/04728/2020.

Conflicts of Interest: The authors declare no conflict of interest.

\section{References}

1. Kotabe, M.M.; Helsen, K. Global Marketing Management; John Wiley \& Sons: Hoboken, NJ, USA, 2020.

2. Mühlbacher, H.; Leihs, H.; Dahringer, L. International Marketing: A Global Perspective, 3rd ed.; The Guilford Press: New York, NY, USA, 2006.

3. Arndt, C.; Buch, C.M.; Mattes, A. Disentangling barriers to internationalization. Can. J. Econ./Rev. Can. D'économique 2012, 45, 41-63. [CrossRef]

4. Cahen, F.R.; Lahiri, S.; Borini, F.M. Managerial perceptions of barriers to internationalization: An examination of Brazil's new technology-based firms. J. Bus. Res. 2016, 69, 1973-1979. [CrossRef]

5. Simões, V. Estratégias de Internacionalização das Empresas Portuguesas. Comércio e Investimento Internacional ICEP. Portugal. Investimentos; Comércio e Turismo de Portugal (edição): Covilhã, Portugal, 1997.

6. Barber, J.; Darder, F. Direccion de Empresas Internacionales; Pearson: Madrid, Spain, 2004.

7. Meyer, R. The Internationalization Process of the Firm Revisited: Explaining Patterns of Geographic Sales Expansion; Management Report; Erasmus University Roterdam: Roterdão, The Netherlands, 1996.

8. Onkvisit, S.; Shaw, J.J. Process of International Marketing. International Marketing: Analysis and Strategy, 4th ed.; Routledge: Estados Unidos, DC, USA, 2004.

9. Leonidou, L.C. Barriers to export management: An organizational and internationalization analysis. J. Int. Manag. 2000, 6, 121-148. [CrossRef]

10. Miesenbock, K.J. Small Businesses and Exporting: A Literature Review. Int. Small Bus. J. 1988, 6, 42-61. [CrossRef]

11. Erraach, Y.; Jaafer, F.; Radić, I.; Donner, M. Sustainability Labels on Olive Oil: A Review on Consumer Attitudes and Behavior. Sustainability 2021, 13, 12310. [CrossRef]

12. Roy, A.; Sekhar, C.; Vyas, V. Barriers to internationalization: A study of small and medium enterprises in India. J. Int. Entrep. 2016, 14, 513-538. [CrossRef]

13. Niñerola, A.; Sánchez-Rebull, M.-V.; Hernandez-Lara, A.-B. Entry modes and barriers to internationalisation in China: An overview of management consulting firms. Meas. Bus. Excel. 2017, 21, 37-49. [CrossRef]

14. Bilkey, W.J. An Attempted Integration of the Literature on the Export Behavior of Firms. J. Int. Bus. Stud. 1978, 9, 33-46. [CrossRef]

15. Okpara, J.O.; Kabongo, J.D. Export barriers and internationalisation: Evidence from SMEs in an emergent African economy. Int. J. Bus. Glob. 2010, 5, 169. [CrossRef]

16. Chandra, A.; Paul, J.; Chavan, M. Internationalization barriers of SMEs from developing countries: A review and research agenda. Int. J. Entrep. Behav. Res. 2020, 26, 1281-1310. [CrossRef]

17. Leonidou, L.C. An Analysis of the Barriers Hindering Small Business Export Development. J. Small Bus. Manag. 2004, 42, 279-302. [CrossRef]

18. Katsikeas, C.S.; Morgan, R.E. Differences in Perceptions of Exporting Problems Based on Firm Size and Export Market Experience. Eur. J. Mark. 1994, 28, 17-35. [CrossRef]

19. Rahman, M.; Akter, M.; Odunukan, K.; Haque, S.E. Examining economic and technology-related barriers of small-and mediumsized enterprises internationalisation: An emerging economy context. Bus. Strategy Dev. 2020, 3, 16-27. [CrossRef]

20. Morais, F.; Franco, M. The role of cooperative alliances in internationalization strategy: Qualitative study of Portuguese SMEs in the textile sector. J. Strategy Manag. 2018, 11, 461-482. [CrossRef]

21. Braga, V.; Gonçalves, A.C.; Braga, A. The Portuguese textile industry business co-operation: Informal relationships for international entry. Rom. Rev. Precis. Mech. Opt. Mechatron. 2016, 49, B52.

22. Rua, O.; França, A.; Ortiz, R.F. Key drivers of SMEs export performance: The mediating effect of competitive advantage. J. Knowl. Manag. 2018, 22, 257-279. [CrossRef]

23. Bank of Portugal. Nota de Informação Estatística: Análise Setorial da Indústria dos Têxteis e Vestuário 2012-2016 (Statistical Information Note: Sectoral Analysis of the Textile and Clothing Industry; Bank of Portugal: Lisbon, Portugal, 2018.

24. Teixeira, S.; Diz, H. Estratégias de Internacionalização; Publisher Team: Lisboa, Portugal, 2005. 
25. Freire, A. Estratégia: Sucesso em Portugal; Editorial Verbo: Lisboa, Portugal, 1997.

26. Lorga, S. Internacionalização e Redes de Empresas: Conceitos e Teorias; Editorial Verbo: Lisboa, Portugal, 2003.

27. Hollensen, S. Essential of Global Marketing; Pearson Education Limited: Harlow, UK, 2008.

28. Tatoglu, E.; Demirbag, M.; Kaplan, G. Motives for Retailer Internationalization to Central and Eastern Europe. Emerg. Mark. Finance Trade 2003, 39, 40-57. [CrossRef]

29. Katsikeas, C.S.; Deng, S.L.; Wortzel, L.H. Perceived Export Success Factors of Small and Medium-Sized Canadian Firms. J. Int. Mark. 1997, 5, 53-72. [CrossRef]

30. Bell, J. The internationalization of small computer software firms: A further challenge to stages theory. Eur. J. Mark. 1995, 29, 60-75. [CrossRef]

31. Tybejee, T.T. Internationalization of high tech firms: Initial vs. extended involvement. J. Glob. Mark. 1994, 7, 59-82. [CrossRef]

32. Williams, D.A. Export stimulation of micro- and small locally owned firms from emerging environments: New evidence. J. Int. Entrep. 2008, 6, 101-122. [CrossRef]

33. Cavusgil, S.T. Differences among Exporting Firms Based on Their Degree of Internationalisation. J. Bus. Res. 1984, 12, 195-208. [CrossRef]

34. Leonidou, L.C. Factors Stimulating Export Business: An Empirical Investigation. J. Appl. Bus. Res. 2011, 14, 43-68. [CrossRef]

35. Tesar, G.; Tarleton, J.S. Comparison of Wisconsin and Virginia small and medium-sized exporters: Aggressive and passive exporters. Export. Manag. Int. Context 1982, 2, 85-112.

36. Barnes, B.R.; Chakrabarti, R.; Palihawadana, D. Investigating the export marketing activity of SMEs operating in international healthcare markets. J. Med. Mark. 2006, 6, 209-221. [CrossRef]

37. Karafakioglu, M. Export Activities of Turkish Manufacturers. Int. Mark. Rev. 1986, 3, 34-43. [CrossRef]

38. Rabino, S. An examination of barriers to exporting encountered by small manufacturing firm. Manag. Int. Rev. 1980, $20,67-73$.

39. Rundh, B. International marketing behaviour amongst exporting firms. Eur. J. Mark. 2007, 41, 181-198. [CrossRef]

40. Fillis, D. The internationalisation process of the craft micro-enterprise. J. Dev. Entrep. 2002, 7, 25-43.

41. Child, J.; Rodrigues, S.B. The internationalization of Chinese firms: A case for theoretical extension? Manag. Organ. Rev. 2005, 1, 381-410. [CrossRef]

42. Singh, D.A.; Gaur, A.S.; Schmid, F.P. Corporate diversification, TMT experience, and performance. Manag. Int. Rev. 2010, 50, 35-56. [CrossRef]

43. Johanson, J.; Vahlne, J.-E. The Uppsala Internationalization Process Model Revisited: From Liability of Foreignness to Liability of Outsidership. J. Int. Bus. Stud. 2009, 40, 1411-1431. [CrossRef]

44. Morais, F.; Ferreira, J. SME internationalisation process: Key issues and contributions, existing gaps and the future research agenda. Eur. Manag. J. 2020, 38, 62-77. [CrossRef]

45. Da Rocha, A.; Kury, B.; Monteiro, J. The diffusion of exporting in Brazilian industrial clusters. Entrep. Reg. Dev. 2009, 21, 529-552. [CrossRef]

46. Pinho, J.C.; Martins, L. Exporting barriers: Insights from Portuguese small- and medium-sized exporters and non-exporters. J. Int. Entrep. 2010, 8, 254-272. [CrossRef]

47. Kuada, J. Internationalisation of firms in developing countries: Towards an integrated conceptual framework. Int. Bus. Econ. 2006, 43, 1-22.

48. Craveiro, R.P.C. Motivações e Barreiras à Internacionalização. Ph.D. Thesis, University of Beira Interior, Covilhã, Portugal, 18 December 2018.

49. Arteaga-Ortiz, J.; Fernández-Ortiz, R. Why Don't We Use the Same Export Barrier Measurement Scale? An Empirical Analysis in Small and Medium-Sized Enterprises. J. Small Bus. Manag. 2010, 48, 395-420. [CrossRef]

50. Kahiya, E.T. Export barriers and path to internationalization: A comparison of conventional enterprises and international new ventures. J. Int. Entrep. 2013, 11, 3-29. [CrossRef]

51. Uner, M.M.; Kocak, A.; Cavusgil, E.; Cavusgil, S.T. Do barriers to export vary for born globals and across stages of internationalization? An empirical inquiry in the emerging market of Turkey. Int. Bus. Rev. 2013, 22, 800-813. [CrossRef]

52. Paul, J.; Parthasarathy, S.; Gupta, P. Exporting challenges of SMEs: A review and future research agenda. J. World Bus. 2017, 52, 327-342. [CrossRef]

53. Rutashobya, L.; Jaensson, J. Small firms' internationalization for development in Tanzania. Int. J. Soc. Econ. 2004, 31, 159-172. [CrossRef]

54. European Commission. The Enlarging European Union at the United Nations: Making Multilateralism Matter; Commission of the European Communities: Brussels, Belgium, 2004.

55. OECD. OECD SME and Entrepreneurship Outlook: 2005; OECD: Paris, France, 2005.

56. Freeman, S.; Reid, I. Constraints facing small western firms in transitional markets. Eur. Bus. Rev. 2006, 18, 187-213. [CrossRef]

57. Fletcher, D. International entrepreneurship and the small business. Entrep. Reg. Dev. 2004, 16, 289-305. [CrossRef]

58. Suarez-Ortega, S. Export barriers: Insights from small and medium-sized firms. Int. Small Bus. J. 2003, 21, 403-419. [CrossRef]

59. Pfeffer, J.; Salancik, G.R. The External Control of Organizations: A Resource Dependence Perspective; Stanford University Press: Palo Alto, CA, USA, 2003.

60. Drees, J.M.; Heugens, P.P. Synthesizing and extending resource dependence theory: A meta-analysis. J. Manag. 2013, 39, 1666-1698. [CrossRef] 
61. Pfeffer, J. A resource dependence perspective on intercorporate relations. Intercorporate Relat. Struct. Anal. Bus. 1988, 1, 25-55. [CrossRef]

62. Hillman, A.J.; Withers, M.C.; Collins, B.J. Resource Dependence Theory: A Review. J. Manag. 2009, 35, 1404-1427. [CrossRef]

63. Haahti, A.; Madupu, V.; Yavas, U.; Babakus, E. Cooperative strategy, knowledge intensity and export performance of small and medium sized enterprises. J. World Bus. 2005, 40, 124-138. [CrossRef]

64. Hessels, J.; Parker, S.C. Constraints, internationalization and growth: A cross-country analysis of European SMEs. J. World Bus. 2013, 48, 137-148. [CrossRef]

65. APT. Annual Report Directory 2019. 2019. Available online: //atp.pt/wp-content/uploads/2019/06/ATP-Diretorio-2019-1.pdf (accessed on 1 March 2021).

66. Vaz, P.; Agiz, D. ROADMAP Para a Especialização Inteligente e Competitividade Global da ITV Portuguesa. 2017. Available online: https:/ /atp.pt/wp-content/uploads/2019/06/RoadMap.pdf (accessed on 1 March 2021).

67. Yin, R.K. Case Study Research and Applications: Design and Methods, 6th ed.; SAGE Publications: Los Angeles, London, 2017.

68. Altinay, M.; Hussain, K. Sustainable tourism development: A case study of North Cyprus. Int. J. Contemp. Hosp. Manag. 2005, 17, 272-280. [CrossRef]

69. Perren, L.; Ram, M. Case-study method in small business and entrepreneurial research-Mapping boundaries and perspectives. Int. Small Bus. J. 2004, 22, 83-101. [CrossRef]

70. Lune, H.; Berg, B.L. Qualitative research methods for the social sciences; Pearson: London, UK, 2017.

71. Rowley, J. Using case studies in research. Manag. Res. News 2002, 25, 16-27. [CrossRef]

72. Tuli, F. The Basis of Distinction Between Qualitative and Quantitative Research in Social Science: Reflection on Ontological, Epistemological and Methodological Perspectives. Ethiop. J. Educ. Sci. 2011, 6, 97-108. [CrossRef]

73. Benbasat, I.; Goldstein, D.K.; Mead, M. The Case Research Strategy in Studies of Information Systems. MIS Q. 1987, 11, 369. [CrossRef]

74. Creswell, J.W. Research Design: Qualitative, Quantitative, and Mixed Methods Approaches; Sage: Thousand Oaks, CA, USA, 2009.

75. Sousa, F. Portugal 1997-A internacionalização em dez tópicos. Econ. Prospect. 1997, 1, 9-16.

76. Solberg, C.A.; Durrieu, F. Strategy development in international markets: A two tier approach. Int. Mark. Rev. 2008, 25, 520-543. [CrossRef]

77. Czinkota, M.R. International Business, 5th ed.; The Dryden Press: Orlando, FL, USA, 1999.

78. Buckley, P.C. Historic and Emergent Trends in Chinese Outward Direct Investment. Manag. Int. Rev. 2008, 48, 715-747. [CrossRef]

79. Welch, L.S.; Luostarinen, R. Internationalization: Evolution of a Concept. J. Gen. Manag. 1988, 14, 34-55. [CrossRef]

80. Vahlne, J.E.; Wiedersheim-Paul, F. Psychic Distance: An Inhibiting Factor in International Trade; Centre for International Business Working Paper Series; University of Uppsala: Uppsala, Sweden, 1977.

81. Onkelinx, J.; Sleuwaegen, L. Internationalization of SMEs; Flanders DC: Leuven, Belgium, 2008.

82. Etemad, H. Internationalization of Small and Medium-sized Enterprises: A Grounded Theoretical Framework and an Overview. Can. J. Adm. Sci. 2009, 21, 1-21. [CrossRef]

83. De Clercq, D.; Sapienza, H.J.; Crijns, H. The Internationalization of Small and Medium-Sized Firms. Small Bus. Econ. 2005, 24, 409-419. [CrossRef]

84. Shaw, V.; Darroch, J. Barriers to internationalization: A study of entrepreneurial new ventures in New Zealand. J. Int. Entrep. 2004, 2, 327-343. [CrossRef]

85. Acs, Z.J.; Morck, R.; Shaver, J.M.; Yeung, B. The Internationalization of Small and Medium-Sized Enterprises: A Policy Perspective. Small Bus. Econ. 1997, 9, 7-20. [CrossRef]

86. Oviatt, B.M.; McDougall, P.P. Defining International Entrepreneurship and Modeling the Speed of Internationalization. Entrep. Theory Pr. 2005, 29, 537-553. [CrossRef]

87. Leonidou, L.C. Empirical Research on Export Barriers: Review, Assessment, and Synthesis. J. Int. Mark. 1995, 3, 29-43. [CrossRef]

88. Ngo, H.T.T.; Igwe, P.A. Internationalization of Firms and Entrepreneur's Motivations: A Review and Research Agenda. In Societal Entrepreneurship and Competitiveness; Dana, L.-P., Ratten, V., Eds.; Emerald Publishing Limited: Bingley, UK, 2019 ; pp. $29-46$. 